ADRIANA STAN ${ }^{1}$

\title{
GENRES OF REALISM ACROSS THE FORMER COLD WAR DIVIDE. NEOLIBERAL NOVELS AND SELF-FICTION
}

\begin{abstract}
After having long struggled at the peripheries of the (post)modernist system of literary values, realism made a landslide return around the turn of the millennium in several genres of the narrative ranging from the more traditional novel of social observation to the more experimental forms of autobiography. In general, the shift to authenticity now witnessed in many literatures across the globe was seen as a momentous response to the collapse of the grand ideological narratives which had confined the Cold War cultural production ${ }^{2}$. Many critics regarded this new stage of fiction, which was reflected in the post-theoretical age of literary studies, as a salutary retrieval of emotion and transparency after the demise of the bookish postmodernism. Other theorists, mostly coming from outside literary studies, doubted that the various realisms emerging after the end of the Cold War were still able to maintain a "realist" vantage point. On defining "capitalist realism", Mark Fisher argued that the globalization of capitalism had entrapped arts themselves within an inescapable ideological worldview that reduced their ability to assume a critical distance ${ }^{3}$. It is true that the classic nineteenth-century age of realism benefitted from a fresh critical approach, once it became the cornerstone of Franco Moretti's seminal research on the world-system developments of the novel. But even so, the recasting of contemporary realist fiction in critical studies still lagged behind (at least compared to the huge attention bestowed on new realism in cinema), mostly due to the bad repute that realism had inherited from the heyday of modernism and postmodernism. As a 2012 issue of Modern Language Quarterly pointed out, once devalued by socialist realism, realism became "peripheral" in the Cold War system of aesthetic values and was neglected by poststructuralist and even postcolonial studies (which favoured more sophisticated types of writing coming on the heels of their Frankfurt School credentials) ${ }^{4}$.
\end{abstract}

\footnotetext{
${ }^{1}$ This work was supported by a grant of the Romanian Ministry of Education and Research, CNCSUEFISCDI, project number PN-III-P1-1.1-TE-2016-0541, Contract 140/2018.

${ }^{2}$ See Ulla Haselstein, Andrew S. Gross, MaryAnn Snyder-Körber (eds.), The Pathos of Authenticity: American Passions of the Real, Heidelberg, Universitätsverlag, 2010; Wolfgang Funk, The Literature of Reconstruction: Authentic Fiction in the New Millennium, New York, Bloomsbury, 2017; Ellen Rutten, Sincerity after Communism. A Cultural History, New Haven, Yale University Press, 2017.

${ }^{3}$ Passim Mark Fisher, Capitalist Realism: Is There No Alternative?, New Alresford, O Books, 2009.

${ }^{4}$ Joe Cleary, Jed Esty, Colleen Lye (eds.), "Peripheral Realisms Now", Modern Language Quarterly, 73, 2012, 3, pp. 255-268.
} 
Anglo-American criticism has recently made several attempts to relate the post-Cold War revival of realism to the ideological conditions of globalized neoliberalism. In their argument to a special issue about "Genres of Neoliberalism", Jane Elliott and Gillian Harkins address from the very beginning the fluid semantics of the said notion. Although already working as a buzzword in contemporary literary studies, "neoliberalism" remains a rather unspecific notion which could in turn stand for a set of institutions and social practices, or for a larger pattern of "uneven development and distribution that is distinct from earlier phases of colonialism and imperialism" and in which privatization and deregulation take place within geopolitical (not national) relations of production. This variable meaning might suggest why the often-referenced term of "neoliberalism" lacks the explanatory power that "bourgeois capitalism" used to have for nineteenth-century realism. Equally telling is the fact that, while the Bildungsroman and the historical novel were genres corresponding to the rise of capitalism, globalized capitalism cannot be directly equated to a certain aesthetic form which would "acknowledge the shared social space that writers and readers inhabit"5.

In line with Mark Fisher's notion of "capitalist realism", theorists of "the neoliberal novel" tend to see behind the authenticity and the return to mimesis claimed by recent fiction a resignation with the inevitability of neoliberalism, and the failure to disrupt, or at least challenge its status-quo, by commenting upon relations of capital. Paradoxically, this sceptical view of the new realism is partly reminiscent of Fredric Jameson's depiction of postmodernism as "the cultural logic of late capitalism" that was unable to establish a critical distance toward relations of capital. The proponents of "capitalist realism" and the "neoliberal novel" agree on both sides that none of the said ideological-aesthetic modes display the distinctive register of older forms of realism. For this reason, they try to define these notions in the negative, rather than by a positive set of features. In their view, the new genres of realism tend to "incorporate other genres", or resort to "indeterminacy and contradiction" in order to "show the processes of their own commodification". Within the ideological enclosure posited by capitalist realism, forms of literary realism such as "neoliberal novels" might attempt to record "the transformative capitalist processes of commodification and financialization", but they remain unable to transcend their hesitation between "conservative and critical impulses" 6 .

In their more focused accounts of the genre, Walter Benn Michaels and Jeffrey J. Williams reinforce the idea that neoliberal novels reproduce contemporary economic paradigms and reigning ideologies, which undermines their tenets of

\footnotetext{
${ }^{5}$ Jane Elliott, Gillian Harkins, "Introduction: Genres of Neoliberalism”, Social Text, 31, 2013, 2, pp. 1-15.

${ }^{6}$ Alison Shonkwiler, Leigh Claire La Berge (eds.), "Introduction: A Theory of Capitalist Realism", in Reading Capitalist Realism, Iowa City, University of Iowa Press, 2014, pp. 12-15.
} 
critical realism ${ }^{7}$. Due to this underlying compliance with the status-quo, these novels downplay the topics of economic distribution and class inequality that were the usual concerns of realism, and fail to project any prospects of collective political action. Instead, they emphasize topics of identity and self-formation, with the result of naturalizing "the unimaginability of any alternative to neoliberalism" (Michaels) and adhering to the belief that "real action" can only occur "among the rich" (Williams). Within this view, even Jonathan Franzen's renewed novel of social observation falls short of articulating any criticism of the system, but rather replicates the neoliberal emphasis on personal responsibility and individual action. All in all, Michaels and Williams argue that contemporary realist fiction fails to explore other forms of identity outside the mainstream neoliberal subjectivity predicated on the ideal of "free" individual choice.

Alissa G. Karl has a slightly different take on "neoliberal novels", based on the analogy between figures of the body and social formations. In her view, the respective narratives try to interrogate the status of the neoliberal nation-state and the fate of the labouring bodies affected by the collapse of social collectivities. Karl herself acknowledges that neoliberal novels favour topics of personal identity. However, she argues that it is precisely this scenario that can "enact, but also confront contemporary neoliberal capitalism's formulation of bodies and, by extension, social entities"8. For this reason, neoliberal novels thematise corporeality in a manner that is directly indicative of political realities and economic conditions, suggesting the social atomization brought by neoliberal policies:

The metaphorical figuration of the social body via ill, injured, and wasting bodies renders a system that does violence to individual bodies and demonstrates the deterioration of older tropes of social cohesion [...]. Such conditions entail an ambivalent view of the social as both ruptured and emphasized. Having undermined the self-contained and seamless body from the outset, the novel conceives instead of an imperfectly networked social totality that is a function of the neoliberal economic climate that it narrates?

A common thread throughout these attempts to conceptualize the literary genres that address neoliberalism is the tendency to debunk their individualistic focus, and their subsequent scepticism about the prospects of collective political action, as a form of compliance with the neoliberal orthodoxy. This orthodoxy has not been, however, scrutinized in the post-communist literatures that witnessed,

\footnotetext{
7 Walter Benn Michaels, "Model Minorities and the Minority Model-the Neoliberal Novel", in Leonard Cassuto et alii (eds.), The Cambridge History of the American Novel, Cambridge, Cambridge University Press, 2011, pp. 1016-1030; Jeffrey J. Williams, "The Plutocratic Imagination”, Dissent, 60, 2013, 1, p. 95.

8 Alissa G. Karl, “Things Break Apart: James Kelman, Ali Smith, and the Neoliberal Novel”, in Alison Shonkwiler, Leigh Claire La Berge (eds.), Reading Capitalist Realism, p. 65.

${ }^{9}$ Ibidem, p. 72.
} 
almost simultaneously with Western literatures, a millennial shift to realism and authenticity. However, in these literatures, millennial realism resurfaced precisely in connection with radical individualism. The realist turn became apparent in Romanian literature towards the end of the first post-communist decade, when poetry displayed an ethos of transparency that was reminiscent of the Beat rhetoric, while the novel downsized to autobiography in the genre deemed as "self-fiction". Young Romanian prose writers like Ioana Baetica, Ioana Bradea, Adrian Schiop, Ionuţ Chiva, Claudia Golea, Cecilia Ştefănescu, Alexandru Vakulovski or Dragoş Bucurenci provided first-person accounts of drifting through the desolate landscape of post-communism. The protagonists of these self-narratives recorded their heightened experiences of corporeality and often reached the brink of existential despair. They presented themselves as marginals, in an implicit attempt to question community models (that pertained to the family, the city, or the nation), even if the overlap of realism with radical individualism weakened their force of social observation.

Millennial realism occasioned the introduction of "self-fiction" in the Romanian critical vocabulary, as a way to describe the emphasized autobiographical dimension of the new prose. As a literary genre, self-fiction was first theorized in French criticism at the end of the 1970s, when the effects of the poststructuralist/' 68 's rethinking of subjectivity could materialize into fiction. In his 2007 account, Philippe Forest distinguishes self-fiction from other forms of autobiographical writing by the genre's awareness of its own novelistic dimension. $\mathrm{He}$ also relates the emergence of the genre to the rising postmodernism, rather than to the Western entrenchment of neoliberal regimes ${ }^{10}$. Although it reflected the right-leaning tendencies that dominated the French intellectual life of the 1970s80s, this demarcation was also indicative of larger trends within Anglo-American scholarship of the time, which "treated postmodern culture and neoliberal governmentality through different disciplinary and theoretical registers" 11 .

The French-inspired concept of "self-fiction" was widely embraced in Romanian criticism with the realist turn of the 2000s, but its use was faulty from the very beginning, for at least three reasons. First, it was charged with the derogatory connotations of a minor literature, which most critics deemed as unable to transcend its authorial narcissism for better aesthetic goals. Secondly, it was too vague to be distinguished from the wider area of autobiographical writing, or even from the first-person narrative. Thirdly, the identity topics within which the concept was confined were too narrow to accommodate the full range of the ideological stances displayed by the new fiction.

On the other hand, the critical readings of Romanian self-fiction barely addressed the neoliberalism that formed the inescapable background of this new

\footnotetext{
${ }^{10}$ Philippe Forest, Romanul, realul și alte eseuri [The Novel, the Real, and Other Essays]. Translated by Ioan Pop-Curșeu, Cluj-Napoca, Tact, 2008, pp. 144-145.

${ }^{11}$ Jane Elliott, Gillian Harkins, "Introduction: Genres of Neoliberalism”, p. 8.
} 
literary genre due to the aggressive promotion of this kind of discourse during postcommunism. A singular such connection was made by Iulia Popovici in a 2004 review of books by Adrian Schiop and Ioana Băetica. Referring to the frakturist manifestoes joining millennial realism, Popovici observed that the ethical, socialcritical stance taken by these Romanian writers could be likened to the attitude of Ravenhill, Sarah Kane, or Douglas Coupland's fiction in response to the reigning thatcherism of the time. Although written in different historical moments, both types of fiction depict "individuals who were left adrift, were deprived of the support of the social values enjoyed by their parents [...], and had lost the sense of belonging to a family $[\ldots]^{\prime \prime 12}$. Popovici contends that Romanian writers' use of first-person accounts of personal experiences works as a means to expose "the breakdown of the social cohesion", the "alienation and palpable misery of life"13 in post-communist Romania.

But otherwise, Romanian critics interpreted the biographical emphasis of selffiction in existential terms associated with a rather timeless juvenile insurgency. The conversational, slang language employed by Romanian authors of self-fiction added to the impression of anarchic youth, whose depressive drift seemed to suggest a generation-specific identity crisis, instead of hinting at concrete social circumstances. Old guard, but still very influential critics like Nicolae Manolescu could not get past the so-called "self-centredness", "superficiality" and "egotistical sensuality" of these first-person narratives focused on the everyday. Long accustomed to the aestheticised language of the Aesopian prose written during communism, these critics regarded the lack of sophistication displayed by the selfnarratives as an aesthetic deficit ${ }^{14}$.

The bad repute of the Romanian self-fiction was enhanced by the fact that the genre could never catch up with the paradigm-shifting impact of millennial realist poetry, but was most often seen as the mere companion of the latter. As a result of that, self-fiction enjoyed much fewer systematic accounts than the poetry written within the same literary paradigm. Although provided by critics who belonged to the 2000s' generation in terms of age (Adina Dinițoiu, Florina Pîrjol), these accounts either focused on narrow, inter-literary connections (with the poetics of the postmodernist prose of the 1980s), or discussed the background of transition in vague, unconvincing terms. Both Diniţoiu and Pîrjol's references were mainly indebted to French criticism, and, as such, were unlikely to address the political dimensions explored by recent Anglo-American theories of fiction, including those that concerned the slightly similar "neoliberal novel".

\footnotetext{
12 Iulia Popovici, "Fracturi de atitudine" ["Fractured Stances"], Revista 22, 2004, https://revista22.ro/cultura/fracturi-de-atitudine. Accessed December 15, 2020.

${ }^{13}$ Ibidem.

${ }^{14}$ Nicolae Manolescu, Istoria critică a literaturii române. 5 secole de literatură [The Critical History of Romanian Literature. 5 Centuries of Literature], Piteşti, Paralela 45, 2008, p. 1453.
} 
In her overview of post-communist Romanian prose trends, Adina Diniţoiu acknowledges that the post-1989 demise of literature-centrism made writers more aware of social and political changes. However, Dinitoiu reads this new horizon of fiction in the hermeneutic terms provided by François Hartog's concept of "régime d'historicité". Although wide enough to cover a variety of discourses, this frame remains unspecific to the post-communist context. In fact, the reading of post-1990 Romanian novels in terms of their "shift between past-present-future" ignores the social and political particularities of their immediate context and overemphasizes their relation with the communist past. Dinițoiu distinguishes two clear-cut tendencies in the post-communist Romanian prose: on the one hand, the stronger focus on memory and the layered approach on the historical past in the works of older prose writers (most of whom pertain to the 1980s generation), and, on the other hand, the complete oblivion/erasure of the (communist) past in millennial prose which creates an overarching "présentisme". Although she mentions that the latter is also fuelled by the postmodern "consumer hedonism", Dinițoiu admits that the social, economic and political crises of transition are the main triggers of millennial fiction, considering that young writers face rising unemployment, poverty, lack of prospects, and so on. Even so, Dinițoiu overstates millennial prose's stance towards communism, and argues that its self-displayed indifference towards the past only reveals its inability to erase that past. Symptomatic for the young critic's allegiance to Bucharest liberal intellectual elite, her bias towards topics of memory and communism erases significant dimensions of millennial fiction as far as its reaction to contemporary transition is concerned ${ }^{15}$.

The only systematic account of Romanian self-fiction was published by Florina Pîrjol in $2014^{16}$. Here, the author makes commendable efforts to distinguish the 2000s' literary generation from the generation of the 1980s, against several critics' attempts to blend the two creative paradigms together on account of their shared biographical bent. Even so, Pîrjol still keeps the two literary generations close in a dialectical balance whereby millennial fiction simply emerges as the reverse side of the previous generation's postmodernist register. But if de-aestheticisation does single out the new Romanian fiction of the 2000s, it remains unclear why Pîrjol only defines it by features that actually pertain to a more sophisticated aesthetic regime, such as "exaggerated playfulness", "deliberate air of superficiality", "bawdy language", or "denial of conventions". While focusing on close readings and on the interplay of literary forms, the critic downplays the political stance taken by millennial fiction, which she addresses by recycling formulas that were already used to describe the 1980s' fiction: "complete indifference to ideology",

15 Adina Dinițoiu, "Prezentism și mizerabilism în proza douămiistă românească" ["Presentism and Miserabilism in the Prose of the Romanian 2000 Generation"], Transilvania, 2015, 2, pp. 25-29; Adina Dinițoiu, Evoluția și direcțiile prozei românești după 1990 [The Evolution and the Trends of the Romanian Prose after 1989], București, Muzeul Literaturii Române, 2015, p. 109 sqq.

${ }^{16}$ Passim Florina Pîrjol, Carte de identităţi [Books of Identities], București, Cartea Românească, 2014. 
"refusal of the system", "ostentatious frond". However, Pîrjol does little to explain which "system" these young writers rebelled against, or how they could remain indifferent to ideology after getting through the first decade of post-communism.

Without a deeper delve into this context, the 2014 book on self-fiction fails to explain the novelty of the genre in the history of Romanian literature. This happens because Pîrjol blends the genre within the much larger history of autobiographical writing, whose genealogy extends way back to ancient and medieval texts. As far as Romanian literature is concerned, the author also pushes the emergence of selffiction back to the communist age in those cases when the usually (self-)censored autobiographical strand erupted as a call for individual authenticity. This view bypasses the practice of Aesopian language during communism and the fact that the expressive circumstances of the age made the autobiographical drive impossible to be voiced in an overt manner. Most often than not, the "self" displayed in fiction written during late communism emerged as a fictionalized construct, rather than as a biographical given. This was the case of the pre-1989 "self-fiction" cited by Pîrjol, which ranged from the self-referential, experimental texts of the Târgovişte School, to the fictionally layered, quasi-autobiographical narratives of 1980s' writers like Simona Popescu (Exuvii) and Mircea Cărtărescu (Orbitor). However, the young critic goes as far as to consider that even the bookish, postmodern fiction written by Gheorghe Crăciun or Ruxandra Cesereanu might be an instance of "introvert, surrealist self-fiction". Placed beside such writers, millennial realists do gain some sort of symbolic validation, especially given the fact that Cărtărescu embodied the paternal figure the former have striven to define themselves against. At the same time, this enlarged view makes literary categories overlap indistinctly. Eventually, Pîrjol herself has to acknowledge the fact that it would be hard to "identify a pioneer of self-fiction in Romanian literature", "list all local examples", or trace a clear "ideological, historical and aesthetic contour" of the genre ${ }^{17}$.

The hesitant stance taken by these accounts was both conceptual and evaluative. Instead of making direct pronouncements on self-fiction's aesthetic value, most Romanian critics tried to explain the genre by the public demand triggered by the best-selling memoirs and diaries that flooded the literary market after 1989. The most influential literary reviewers of the 2000s (Paul Cernat, Daniel Cristea-Enache) also voiced their suspicion that self-fiction might be just a circumstantial mass genre. In fact, the public appeal of self-fiction was overstated, even if Polirom Publishing House did try to market one of its collections of contemporary fiction by the label of "ego-prose". At the same time, most senior and younger critics alike were reluctant to address the social-political contexts in which millennial realism emerged other than by vaguely mentioning the so-called "disillusionments" of the post-communist transition. Although being the post-

\footnotetext{
${ }^{17}$ See Ibidem.
} 
communist critic with the keenest eye on fiction's underlying ideologies, Mihai Iovănel shares with his aforementioned peers a certain doubt about self-fiction's ability to cast a window into the surrounding social reality. In his 2017 overview of post-communist literature, Iovănel poignantly observes that post-1989 Romanian fiction could not keep up with the pace by which social structures changed during post-communism, and for this reason autobiography was given an "excessive role in the entire post-communist prose" ${ }^{\prime 18}$. He also considers that self-fiction, which is a striking instance of the general tendency toward autobiographical writing, remains basically "a French import". Perhaps surprisingly, but rather in line with the French reading of the genre, Iovănel places self-fiction in the category of the "metarealism" developed from the 1980s postmodernism, because of its experimental nature displayed through the radical "overlap of author, narrator, and character" $" 19$.

All in all, maintaining the French frame of reference, which related to completely different historical circumstances, didn't help much in locating the debate around self-fiction within the neoliberalism on the rise during postcommunism. In fact, the Romanian self-fiction of the 2000s could be productively related to the "neoliberal novel" by their common duplicity that made the selfexpressed claim to realism hide a deeper compliance with the capitalist status-quo. In this respect, the crude narcissism displayed through the Romanian self-fiction was analogical to the economic and political formation of the post-1989 neoliberalism, whose underlying myths of individuation and free choice were reinforced by the rising consumerism and by mainstream media's attempts to project a type of citizen that would pursue his/her own best interests and act on his/her desires unhinged. Romanian writers of self-fiction have emerged from the 1990s' decade that celebrated the liberated individual while confronting people with unprecedented social insecurity, which explains the extreme narrative shape they gave to the post-communist ideal of self-determination. However, the genre had a short life span and faded by the time the 2008 crisis hit Romania. Moreover, it was unable to shake the grounds of the local literary canon, which remains to this day bent on conservative aestheticism, while continuing to be suspicious of the social-political referentiality embedded in literature.

\section{BIBLIOGRAPHY}

CLEARY, Joe, ESTY, Jed, LYE, Colleen (eds.), "Peripheral Realisms Now", Modern Language Quarterly, 73, 2012, 3, pp. 255-268.

\footnotetext{
${ }^{18}$ Mihai Iovănel, Ideologiile literaturii în postcomunismul românesc [The Ideologies of Literature in Romanian Postcommunism], București, Muzeul Literaturii Române, 2017, p. 43.

${ }^{19}$ Ibidem, p. 141.
} 
DINIȚOIU, Adina, "Prezentism şi mizerabilism în proza douămiistă românească" ["Presentism and Miserabilism in the Prose of the Romanian 2000 Generation"], Transilvania, 2015, 2, pp. 25-29.

DINIȚOIU, Adina, Evoluția și direcțiile prozei românești după 1990 [The Evolution and the Trends of the Romanian Prose after 1989], București, Muzeul Literaturii Române, 2015.

ELLIOTT, Jane, HARKINS, Gillian, "Introduction: Genres of Neoliberalism”, Social Text, 31, 2013 2, pp. 1-15.

FISHER, Mark, Capitalist Realism: Is There No Alternative?, New Alresford, O Books, 2009.

FOREST, Philippe, Romanul, realul și alte eseuri, eseuri [The Novel, the Real, and Other Essays]. Translated by Ioan Pop-Curșeu, Cluj-Napoca, Tact, 2008.

FUNK, Wolfgang, The Literature of Reconstruction: Authentic Fiction in the New Millennium, New York, Bloomsbury, 2017.

HASELSTEIN, Ulla, Andrew S. Gross, MaryAnn Snyder-Körber (eds.), The Pathos of Authenticity: American Passions of the Real, Heidelberg, Universitätsverlag, 2010.

IOVĂNEL, Mihai, Ideologiile literaturii în postcomunismul românesc [The Ideologies of Literature in Romanian Postcommunism], București, Muzeul Literaturii Române, 2017.

MANOLESCU, Nicolae, Istoria critică a literaturii române. 5 secole de literatură [The Critical History of Romanian Literature. 5 Centuries of Literature], Piteşti, Paralela 45, 2008.

MICHAELS, Walter Benn, "Model Minorities and the Minority Model-the Neoliberal Novel", in Leonard Cassuto et alii (eds.), The Cambridge History of the American Novel, Cambridge, Cambridge University Press, 2011.

PÎRJOL, Florina, Carte de identităţi [Books of Identities], București, Cartea Românească, 2014.

POPOVICI, Iulia, "Fracturi de atitudine" ["Fractured Stances"], Revista 22, 2004, https://revista22.ro/cultura/fracturi-de-atitudine. Accessed December 15, 2020.

RUTTEN, Ellen, Sincerity after Communism. A Cultural History, New Haven, Yale University Press, 2017.

SHONKWILER, Alison, LA BERGE, Leigh Claire (eds.), Reading Capitalist Realism, Iowa City, University of Iowa Press, 2014.

WILLIAMS, Jeffrey J., “The Plutocratic Imagination”, Dissent, 60, 2013, 1, pp. 93-97.

\section{GENRES OF REALISM ACROSS THE FORMER COLD WAR DIVIDE. NEOLIBERAL NOVELS AND SELF-FICTION}

\section{(Abstract)}

The article explores and correlates two genres of the new literary realism that emerged around the year 2000, as they were conceptualized and instantiated in fiction across the two sides of the Atlantic, in North America and Romania, respectively. The common background of this global wave of realism relates to the post-Cold War definitive entrenchment of neoliberalism and to its corresponding topics of personal identity, which provide the vantage point of the realist social observation. Despite the post-communist critical elite's bias for topics of memory and communism, the genre of "self-fiction" that emerged in millennial Romanian literature shared with the "neoliberal novels" theorized in Anglo-American criticism an underlying compliance with status-quo capitalism and its defining myths of individuality.

Keywords: neoliberalism, realism, individualism, biographical writing, post-communism. 


\title{
GENURI ALE REALISMULUI LA CEI DOI FOȘTI POLI AI RĂZBOIULUI RECE. ROMANUL NEOLIBERAL ȘI AUTOFICȚIUNEA \\ (Rezumat)
}

\begin{abstract}
Articolul dezbate și corelează două genuri ale noului realism literar apărut în jurul anului 2000, așa cum au fost conceptualizate și exemplificate în proză de cele două părți ale Atlanticului, în America de Nord și în România. Fundalul comun al acestui nou val realist îl constituie definitiva instituționalizare a neoliberalismului după încheierea Războiului Rece și privilegierea corespunzătoare a tematicilor ținând de identitatea personală, aceasta fiind și perspectiva din care este realizată observația socială realistă. În ciuda tendinței elitelor critice postcomuniste de a aprecia/supralicita temele memoriei și ale reprezentării comunismului, ,autoficțiunea" dezvoltată în literatura română douămiistă poate fí corelată cu ,romanul neoliberal” teoretizat în critica angloamericană prin prisma raportării similare, duplicitare la status-quo-ul capitalist și la miturile sale specifice privind individualitatea.
\end{abstract}

Cuvinte-cheie: neoliberalism, realism, individualism, biografism, postcomunism. 